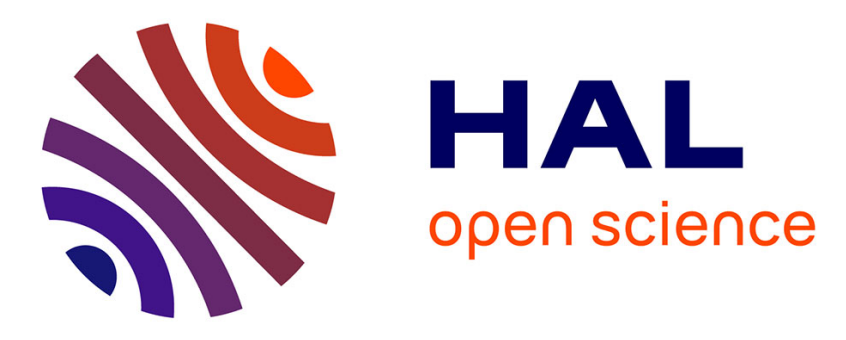

\title{
Selective On/Off-Nitroxides as Radical Probes to Investigate Non-radical Enzymatic Activity by Electron Paramagnetic Resonance
}

Indranil Duttagupta, Natacha Jugniot, Gérard Audran, Jean-Michel Franconi, Sylvain R.A. Marque, Philippe Massot, Philippe Mellet, Elodie Parzy, Eric Thiaudiere, Nicolas Vanthuyne

\section{To cite this version:}

Indranil Duttagupta, Natacha Jugniot, Gérard Audran, Jean-Michel Franconi, Sylvain R.A. Marque, et al.. Selective On/Off-Nitroxides as Radical Probes to Investigate Non-radical Enzymatic Activity by Electron Paramagnetic Resonance. Chemistry - A European Journal, 2018, 24 (30), pp.7615-7619. 10.1002/chem.201800866 . hal-02091903

\section{HAL Id: hal-02091903 \\ https://hal-amu.archives-ouvertes.fr/hal-02091903}

Submitted on 7 Apr 2019

HAL is a multi-disciplinary open access archive for the deposit and dissemination of scientific research documents, whether they are published or not. The documents may come from teaching and research institutions in France or abroad, or from public or private research centers.
L'archive ouverte pluridisciplinaire HAL, est destinée au dépôt et à la diffusion de documents scientifiques de niveau recherche, publiés ou non, émanant des établissements d'enseignement et de recherche français ou étrangers, des laboratoires publics ou privés. 


\title{
Selective On/Off-Nitroxides as Radical Probes to Investigate Non- radical Enzymatic Activity by Electron Paramagnetic Resonance
}

\author{
Indranil Duttagupta ${ }^{+[a]}$ Natacha Jugniot ${ }^{+}{ }^{[b]}$ Gérard Audran, ${ }^{*[a]}$ Jean-Michel Franconi, ${ }^{[b]}$ \\ Sylvain R. A. Marque, ${ }^{[[a, c]}$ Philippe Massot, ${ }^{[b]}$ Philippe Mellet, ${ }^{*[b, d]}$ Elodie Parzy, ${ }^{[b]}$ \\ Eric Thiaudière, ${ }^{[\mathrm{b}]}$ and Nicolas Vanthuyne ${ }^{[\mathrm{e}]}$
}

\begin{abstract}
A nitroxide carrying a peptide specific to the binding pocket of the serine proteases chymotrypsin and cathepsin $G$ is prepared. This peptide is attached as an enol ester to the nitroxide. Upon enzymatic hydrolysis of the peptide, the enol ester moiety is transformed into a ketone moiety. This transformation affords a difference of $5 \mathrm{G}$ in phosphorus hyperfine coupling constant between the electronic paramagnetic resonance (EPR) signals of each nitroxide. This property is used to monitor the enzymatic activity of chymotrypsin and cathepsin G by EPR. Michaelis constants were determined and match those reported for conventional optical probes.
\end{abstract}

In normal tissues enzymatic proteolytic activities are tightly regulated spatially and temporally. However, numerous diseases such as pulmonary inflammatory diseases-asthma, cystic fibrosis (CF), chronic obstructive pulmonary disorder (COPD; e.g., emphysema), acute respiratory distress syndrome and $\alpha$ 1-antitrypsin deficiency-as well as cancers, arthritis and pancreatitis are concomitant to unusually persistent enzymatic ac-

[a] Dr. I. Duttagupta, ${ }^{+}$Prof. G. Audran, Prof. S. R. A. Marque Aix Marseille Univ, CNRS, ICR, UMR 7273, Case 551

Avenue Escadrille Normandie-Niemen, 13397 Marseille Cedex 20 (France) E-mail:g.audran@uni-amu.fr sylvain.marque@univ-amu.fr

[b] N. Jugniot, ${ }^{+}$Prof. J.-M. Franconi, Dr. P. Massot, Dr. P. Mellet, Dr. E. Parzy, Prof. E. Thiaudière

Centre de Résonance Magnétique des Systèmes Biologiques UMR 5536 CNRS, Case 93, University Bordeaux Segalen 146 rue Leo Saignat, 33076 Bordeaux Cedex (France) E-mail:philippe.mellet@rmsb.u-bordeaux2.fr

[c] Prof. S. R. A. Marque

N. N. Vorozhtsov Novosibirsk Institute of Organic Chemistry

Pr. Laurentjeva 9, Novosibirsk, 630090 (Russia)

[d] Dr. P. Mellet INSERM, 33076 Bordeaux Cedex (France)

[e] Dr. N. Vanthuyne

Aix Marseille Univ., CNRS, ISM2, UMR 7313

Avenue Escadrille Normandie-Niemen, 13397 Marseille Cedex 20 (France) tivities. COPD alone ranks as the fifth leading cause of mortality worldwide which affects an estimated 175 million people and accounts for 3.2 million deaths in $2015 .^{[1]}$ Therefore, noninvasive or slightly invasive diagnostic/monitoring techniques are of the utmost interest for efficient management of patients. Molecular imaging of the proteolytic activity is a very appealing approach and has been mainly applied using internally quenched fluorescent substrates. Despite suitable enzymatic constants ${ }^{[2]}$ this method suffers from several drawbacks: incomplete quenching of substrate fluorescence, limited tissue penetration of light, difficult skull imaging or imaging in large animals and three-dimensional images require reconstruction. Due to superior true 3D coding and the used wavelengths interfering weakly with tissues, magnetic resonance imaging methods are the most attractive approach to circumvent the limits of fluorescent techniques. Free radicals such as nitroxides or trityl radicals are stable enough in physiological conditions (in vitro and in vivo) to be detected by electronic paramagnetic resonance (EPR). ${ }^{[3]}$ Interestingly, EPR is a sensitive technique for the detection of free radical, suitable in visible light-opaque media and which reports only on radical species affording, in general, a rather simple signal. Unfortunately, due to the very fast relaxation of free electron, EPR imaging (EPRI) is at the moment slow and insufficiently resolved. ${ }^{[4]}$ On the other hand, magnetic resonance imaging (MRI), which is one of the most powerful methods that delivers exquisite anatomic detail, cannot be applied due to its low sensitivity which limits its applicability in molecular imaging of enzymatic activity. ${ }^{[5]}$ Nevertheless, an emerging double resonance experiment, Overhauser-enhanced magnetic resonance imaging (OMRI), which transfers a part of the higher magnetization of a free radical (nitroxide in this case) to the protons neighboring water molecules (through the electron-proton Overhauser effect), affords a brighter zone on the image and, in turn, the possibility to visualize the site of enzymatic activity. ${ }^{[6]}$ This technique requires the use of a nitroxide providing an EPR signal sensitive to this activity. Indeed, free organic radicals are currently used for oximetry, ${ }^{[7,8]}$ redox status imaging, ${ }^{[9,10]}$ for $\mathrm{pH}$ measurement, ${ }^{[11-14]}$ and for water content measurement. ${ }^{[15]}$ However, none of these approaches can be employed to investigate nonradical enzymatic activity either by EPR or OMRI. Drescher and colleagues have shown that the signal of a nitroxide might be used to report on enzymatic activity using a very tedious experimental procedure. ${ }^{[16]}$ Preliminary investigations in our groups ${ }^{[17-19]}$ indicated that nonradical enzymatic activity can be 
investigated both by EPR and OMRI using signal changes based either on the linewidth broadening effect ${ }^{[17,18]}$ or on the shift ${ }^{[19]}$ of hyperfine coupling constant of a nitroxide. Regardless its lack of selectivity, the approach based on shifting-nitroxides $1 \% \mathbf{2}^{*}$ (Scheme 1 ) was very promising and encouraged us

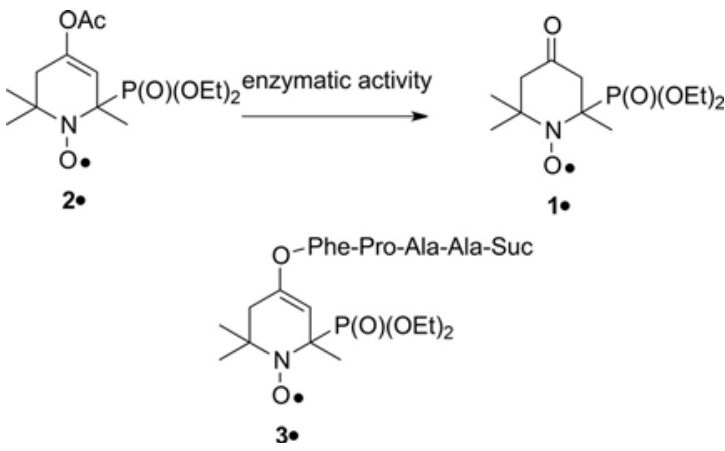

Scheme 1 . Enzymatic activity on enol acetate $2^{\circ}$ releasing $1^{*}$.

to develop radical probes exhibiting high selectivity for enzymes. Here we report the synthesis of a nitroxide probe $\mathbf{3}^{\circ}$ (Scheme 1) specific to chymotrypsin and cathepsin G. Its EPR signal and sensitivity to enzyme catalysis are reported. In brief, the reported peptide-linked nitroxide is highly selective to these two enzymes and reports activities in nanomolar concentrations of enzymes, best among the array of available conventional nonradical probes.

Since enzymes are known to be substrate specific, the peptide-nitroxide $3^{*}$ was designed based on a well-documented substrate for chymotrypsin Suc-Ala-Ala-Pro-Phe. ${ }^{[20]}$ The substrates Suc-Ala-Ala-Pro-Phe-(S)-2* ((S)-3*) and Suc-Ala-Ala-ProPhe- $(R)-2^{*}\left((R)-3^{*}\right)$, which are thought to be selective for the enzymatic activity of chymotrypsin and cathepsin G, were prepared (see the Supporting Information). For this purpose, nitroxide $1^{\cdot}$ was prepared in eight steps from commercially available starting materials 1 (Scheme $2 \mathrm{~A}$ ). The first three steps were performed as previously reported to afford 2 .

Then, Kabachnik-Fields reaction using standard conditions $\left(\mathrm{NH}_{3}, \mathrm{HP}(\mathrm{O})(\mathrm{OEt})_{2}\right)$ afforded the amino-phosphonate 3 in $37 \%$ yield. Consequently, the reaction was repeated under different conditions (e.g., $\mathrm{Mg}\left(\mathrm{ClO}_{4}\right)_{2}, 100^{\circ} \mathrm{C}$, ammonium acetate which also failed to improve the yield of the reaction. ${ }^{[21-25]} \mathrm{A}$ two-step procedure (generation of imine followed by addition of diethyl phosphite ${ }^{[25]}$ also failed to afford the amino-phosphonate $\mathbf{3}$ in good yield. Finally, $10 \mathrm{~mol} \%$ of $\mathrm{FeCl}_{3}$ was found to be an efficient catalyst for this reaction providing the amino-phosphonate $\mathbf{3}$ in $87 \%$ yield. ${ }^{[26]}$ Then, $\mathbf{3}$ was converted into $\boldsymbol{1}^{\boldsymbol{1}}$ in five steps as previously reported. ${ }^{[19]}$ Enantiomers of $\mathbf{1}^{*}$ were separated by using a Chiralpak-IE column $\left(1 \mathrm{a}^{\circ}, t_{\mathrm{R}}=6.21 \mathrm{~min}, \mathbf{1} \mathrm{b}^{\circ}, t_{\mathrm{R}}=\right.$ $7.64 \mathrm{~min}$ in 1:1 heptane/ethanol at $1 \mathrm{~mL} \mathrm{~min}^{-1}$ flow rate).

In order to determine the absolute configuration of the enantiomers of $1^{*}$, enantiomer $1 \mathrm{a}^{*}\left(t_{\mathrm{R}}=6.21 \mathrm{~min}\right.$ in 1:1 heptane/ethanol) was converted into alkoxyamine $\mathbf{4} a$ and $\mathbf{4} b^{[27]}$ for which diastereoisomers were easily purified by silica gel chromatography (Scheme 2B). The less polar ketone $4 \mathrm{a}$ was reduced in the presence of $\mathrm{NaBH}_{4}$, and then esterified using
$(1 S, 4 R)-(-)$-camphanic chloride ${ }^{[28]}$ as the reference chiral center affording 55:45 mixture of diastereoisomers $\mathbf{5} \mathbf{a}$ and $\mathbf{5} \mathbf{b}$, respectively (Scheme 2B and the Supporting Information). After purification, crystals were grown for X-ray crystallography. ${ }^{[29]}$ The XRD structure displays $R$ configuration for the chiral center in nitroxide $1 \mathrm{a}^{*}$ (Figure 1 and Supporting Information).

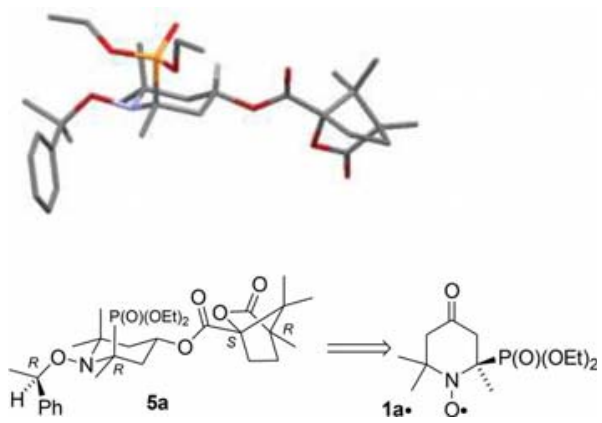

Figure 1. X-ray structures of $5 \mathrm{a}^{[29]}$ and absolute stereochemistry of $1 \mathrm{a}$ :

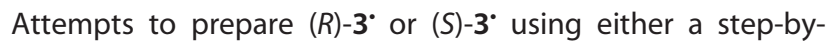
step growth of the peptidic chain or the coupling between the enolate of $\mathbf{1}^{\circ}$ and the beforehand-prepared activated tetrapeptide Fmoc-Ala-Ala-Pro-Phe-X failed to yield the aimed compounds. Thus, nitroxide $(R)-\mathbf{1}^{\cdot}$ was treated ${ }^{[19]}$ with excess of LiHMDS at $-78^{\circ} \mathrm{C}$ and the resulting enolate was trapped with the activated dipeptide Fmoc-L-Pro-L-Phe-O-Piv 6, prepared by treating the commercially available dipeptide Fmoc-L-Pro-LPhe-OH with pivaloyl chloride, ${ }^{[30,31]}$ to yield peptide $(R)-4^{*}$ (82\%). 1,8-Diazabicyclo[5.4.0]undec-7-ene (DBU) ${ }^{[32]}$ mediated Fmoc deprotection of $(R)-4^{*}$, followed by $N, N^{\prime}$-dicyclohexylcarbodiimide (DCC) coupling with commercially available dipeptide, Fmoc-Ala-Ala-OH afforded the tetrapeptide nitroxide $(R)$ $5^{\cdot}$ (13\% for two steps). Peptide nitroxide $(R)-5^{*}$ was then treated with DBU, and then by succinic anhydride in a one-pot procedure to yield substrate $(R)-3^{*}$ as a DBU salt (Scheme $2 C \alpha$ ). The same procedure was applied to $(S) \mathbf{1}^{*}$ to afford (S)-3* (Scheme $2 C \beta)$.

EPR signal of substrates $(R)-3^{*}$ (or (S)-3*) display the expected 6-lines signal (top signal in Figure 2) due to the coupling of odd electron with the nitrogen $\left(I_{N}=1\right)$ and phosphorous $\left(I_{\mathrm{P}}=\right.$ $1 / 2$ ) atoms (few percent of hydrolyzed nitroxide $1^{\circ}$ are also observed). Nitrogen and phosphorus hyperfine coupling constants $a_{\mathrm{N}}\left(a_{\mathrm{N}}=15.5 \mathrm{G}\right)$ and $a_{\mathrm{P}}\left(a_{\mathrm{P}}=38.4 \mathrm{G}\right)$, respectively, are very close to those reported for $2^{\cdot[33]}$ as well as the Landé's factor $g$ $(g=2.0057)$. Upon addition of chymotrypsin, a new pattern arose (Figure 2) comprising signals of both $(R)-3^{*}$ and $(R)-\mathbf{1}^{*}$. After a while, complete hydrolysis of $(R)-3^{\cdot}$ was observed as only the EPR signal ${ }^{[19]}$ of $\boldsymbol{1}^{\bullet}$ is recorded (bottom signal in Figure 2).

The clear difference between substrate $3^{\circ}$ and the hydrolyzed nitroxide $1^{\circ}$ observed by EPR affords an easy quantification of each species over time. Thus, the selectivity of $(R)-3^{*}$ and (S)-3' was investigated with several serine proteases: chymotrypsin, trypsin, porcine pancreatic elastase (PPE), cathepsin $G$ and neutrophil elastase (NE). Initial velocity values show a 
A)

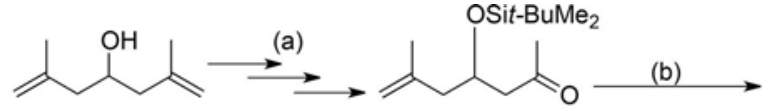<smiles>C=C(C)CC(CC(C)(N)P(C)(C)(C)C)OCC</smiles>

2<smiles>CCOC(=O)C1(C)CC(=O)CC(C)(C)N1OCC</smiles>

B)

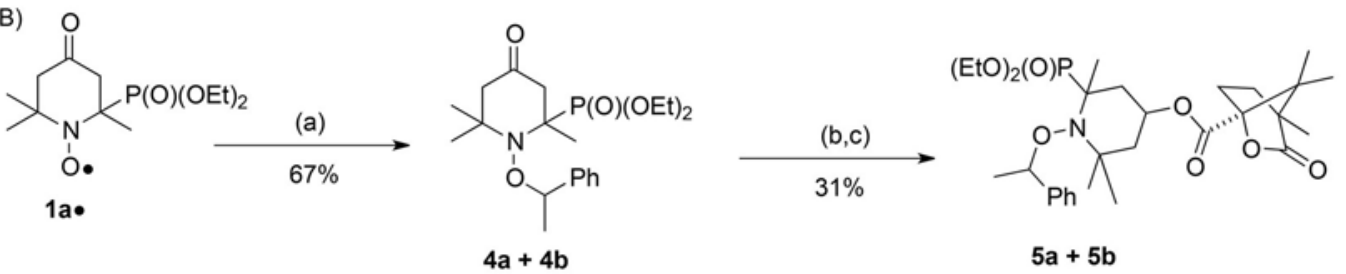

C)

$(\alpha)$

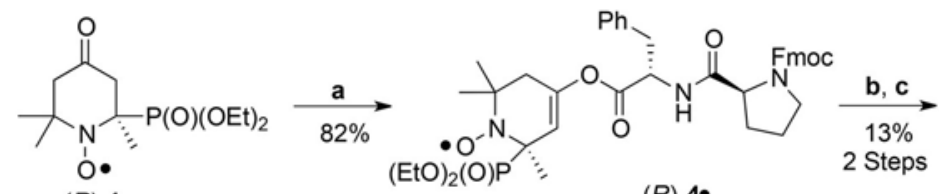

(R)-1॰

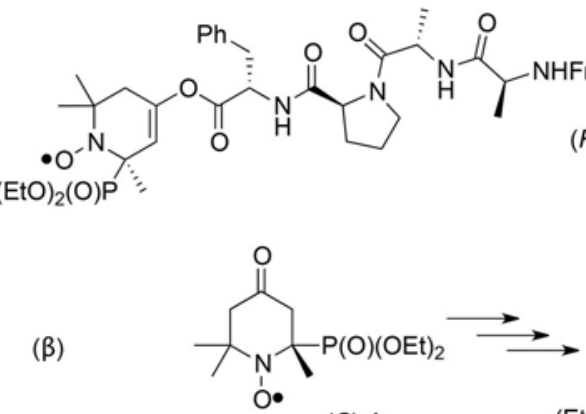

(S)-1•
$(\mathrm{EtO})_{2}(\mathrm{O}) \mathrm{P}$
(R)-4e
2 Steps

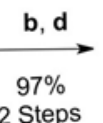

2 Steps

$(\mathrm{EtO})_{2}(\mathrm{O}) \mathrm{P}:$

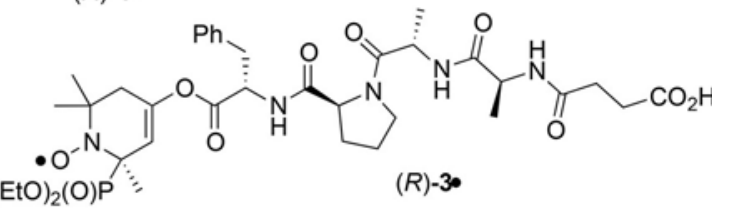

(R)-30

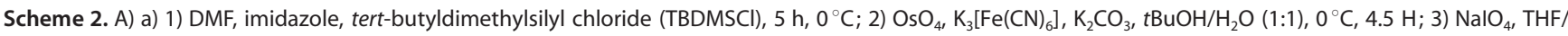
water (1:3, v/v), $3 \mathrm{~h}, 0{ }^{\circ} \mathrm{C}$. b) $\mathrm{FeCl}_{3}(10 \mathrm{~mol} \%), \mathrm{HP}(\mathrm{O})(\mathrm{OEt})_{2}, \mathrm{NH}_{3}, 4 \AA \mathrm{MS}, 24 \mathrm{~h}, \mathrm{RT}$. c) 1$) \mathrm{Hg}(\mathrm{OAc})_{2}, \mathrm{THF} /$ water $\left.(1: 3, \mathrm{v} / \mathrm{v}), 30 \mathrm{~min}, \mathrm{RT} ; 2\right) \mathrm{NaBH}$, NaOH (1 M); 3$)$ metachloroperoxybenzoic acid (mCPBA), $\mathrm{CH}_{2} \mathrm{Cl}_{2}, 2 \mathrm{~h}, 0^{\circ} \mathrm{C}$; 4 ) TBAF, THF, $3 \mathrm{~h}, 0{ }^{\circ} \mathrm{C}$; 5) NMO, TPAP, $4 \AA \mathrm{MS}^{\circ} \mathrm{CH}_{2} \mathrm{Cl}_{2}, 0^{\circ} \mathrm{C}$. B) Determination of the configuration of $1 \mathrm{a}$ : (a) $\mathrm{Cu}, \mathrm{CuBr}_{2}$, PMEDTA, benzene, rt, $12 \mathrm{~h}$. (b) $\mathrm{NaBH}_{4} / \mathrm{MeOH}, \mathrm{THF}, 0^{\circ} \mathrm{C}, 2 \mathrm{~h}$; c) (-)-camphanoyl chloride, $\mathrm{Et}_{3} \mathrm{~N}, \mathrm{dry}_{\mathrm{CH}} \mathrm{Cl}_{2}, 0{ }^{\circ} \mathrm{C}, 1 \mathrm{~h}$. C) Synthesis of chymotrypsin substrate $(R)-3^{\circ}(\alpha)$ and $(S)-3^{\circ}(\beta)$. Reagents and conditions: a) LiHMDS, 6, THF, -78 to $-45^{\circ} \mathrm{C}$; b) DBU, DCM, $0^{\circ} \mathrm{C}, 3 \mathrm{~h}$; c) Fmoc-L-Ala-L-Ala-OH, DCC, HOBT, $\mathrm{DCM}, 0^{\circ} \mathrm{C}$ to RT, $18 \mathrm{~h}$; d) succinic anhydride, $\mathrm{DCM}, 0^{\circ} \mathrm{C}$ to $\mathrm{RT}, 6 \mathrm{~h}$.

strong selectivity of the substrate $(R)-3^{*}$ for chymotrypsin and cathepsin $G$ (Figure 3). The rates of consumption of $(R)-3^{*}$ by other proteases such as trypsin, PPE and HNE do not differ significantly from its spontaneous hydrolysis (SD in Figure 3). Interestingly, at concentration as low as $2 \mathrm{~nm}$, protease chymotrypsin and neutrophil protease cathepsin $G$ exhibit a high rate of hydrolysis at $V_{0}=24( \pm 2) \mathrm{nm} \mathrm{s}^{-1}$. This selectivity is identical to the one displayed by para-nitroanilide ( $p N A)$ substrates and stems from the almost exclusive preference of these two enzymes for large aromatic amino-acids at the $\mathrm{P}_{1}$ position. ${ }^{[34]}$ Similar selectivity is observed for (S)-3:

For the determination of the Michaelis constants $K_{\mathrm{M}}$ and $k_{\text {cat }}$ with chymotrypsin, substrate to product conversion was monitored using EPR spectroscopy by varying the concentration of substrates $\mathbf{3}^{*}$, at constant concentration of chymotrypsin (Fig- ure $4 \mathrm{a}$ and $\mathrm{b}$ ). Initial velocities $V_{0}$ were measured for each curve and plotted against the concentration of nitroxide (Michaelis-Menten plots Figure 4c). Michaelis constants $K_{\mathrm{M}}$ and catalysis rate constant $k_{\text {cat }}$ were estimated by fitting with [Eq. (1)]:

$V_{0}=\frac{k_{\mathrm{cat}} \cdot[\mathrm{E}][\mathrm{S}]_{0}}{K_{\mathrm{M}}+[\mathrm{S}]_{0}}$

As shown in Table 1, both enantiomers display comparable values for the Michaelis constant and, hence, a very similar catalytic efficiency $k_{\text {cat }} / K_{\mathrm{M}}$ of $3.5( \pm 1.0) 10^{6} \mathrm{~s}^{-1} \mathrm{M}^{-1}$. It is worth noting that $3^{*}$ exhibits a 15 - to 18 -fold higher values for $K_{\mathrm{M}}$ than reported for the widely used chromogenic substrate SucAla-Ala-Pro-Phe-pNA along with a 6- to 11-fold higher catalytic 


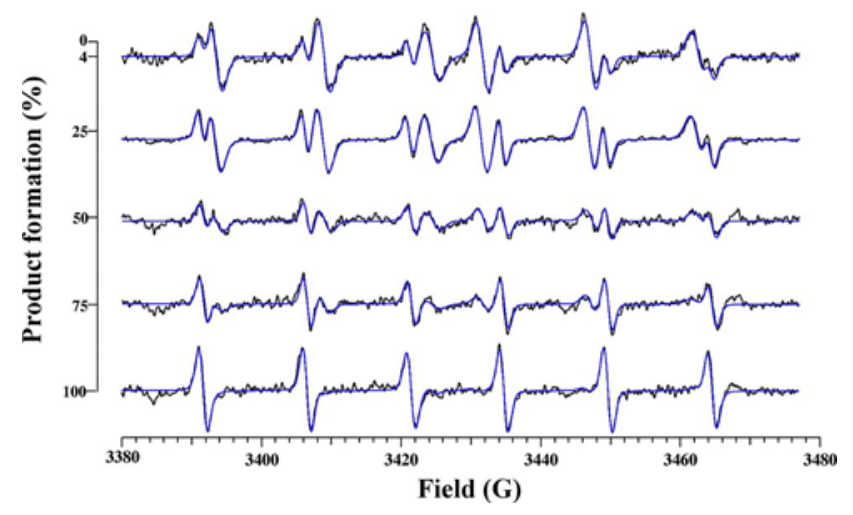

Figure 2. EPR signals of the proteolysis of $50 \mu \mathrm{M}$ substrate $(R)-3^{*}$ by chymotrypsin ( $2 \mathrm{~nm}$ ) to product $1^{\circ}$ (conversion from top to down: 4, 25, 50, 75, $100 \%)$. Blue lines are for the EPR simulations using hyperfine coupling constants given in the text and in ref. [19] (see the Supporting Information for details).

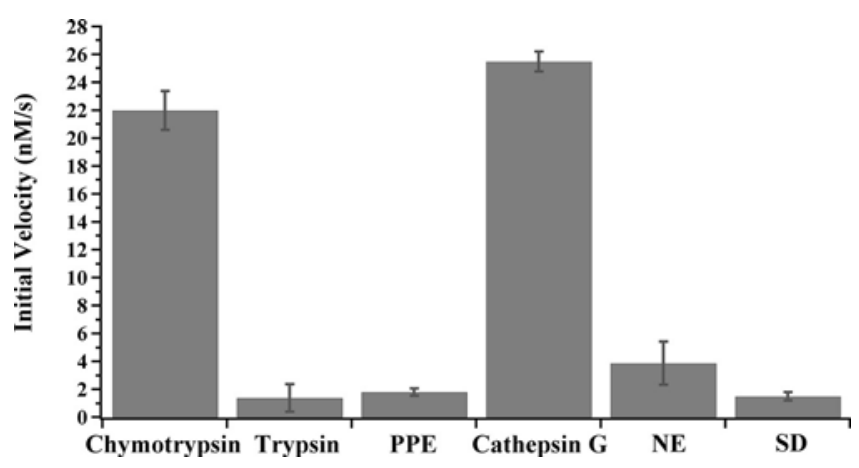

Figure 3. EPR comparative kinetics of hydrolysis of the substrate isomer $(R)$ $3^{\circ}(1 \mathrm{~mm})$ by five serine proteases $(2 \mathrm{nM})$ at $25^{\circ} \mathrm{C}$ : chymotrypsin, trypsin, porcine pancreatic elastase (PPE), cathepsin $\mathrm{G}$ and neutrophil elastase (NE). Substrate spontaneous dissociation in HEPES buffer is given as SD. Error bars for the two limit values of duplicate experiments.

\begin{tabular}{|lll|}
\hline Table 1. Enzyme-substrate Michaelis constants for $(R)-3^{*}$ and $(S)-3^{*}$ \\
& $(R)-3^{*}$ & $(S)-3^{*}$ \\
\hline$K_{\mathrm{M}}[\mu \mathrm{M}]$ & $6 \pm 1.6$ & $5 \pm 1.2$ \\
$k_{\mathrm{cat}}\left[\mathrm{s}^{-1}\right]$ & $15 \pm 0.7$ & $22 \pm 1.1$ \\
$k_{\mathrm{cat}} / K_{\mathrm{M}}\left[\mathrm{s}^{-1} \mathrm{M}^{-1}\right]$ & 2500000 & 4400000 \\
\hline
\end{tabular}

efficiency. ${ }^{[2]}$ These significantly better affinity and turnover occurring between chymotrypsin and substrates $3^{*}$ suggests that the nitroxide leaving group has a stronger interaction with the $S^{\prime}$ part of the enzyme than the para-nitroanilide group according to the Schechter and Berger nomenclature. ${ }^{[35]}$

In summary, these experiments exemplify that on/off nitroxides are suitable to probe nonradical enzymatic activity. Moreover, as EPR is able to probe nontransparent media such as blood or tissue samples from biopsies or from medical research experiments, and reports only on radical species (and here only stable free organic radicals) affording a very simple signal irrespective of the conditions. As the substrates reported above show negligible hydrolysis at $\mathrm{pH} 7.4$ they are legible for
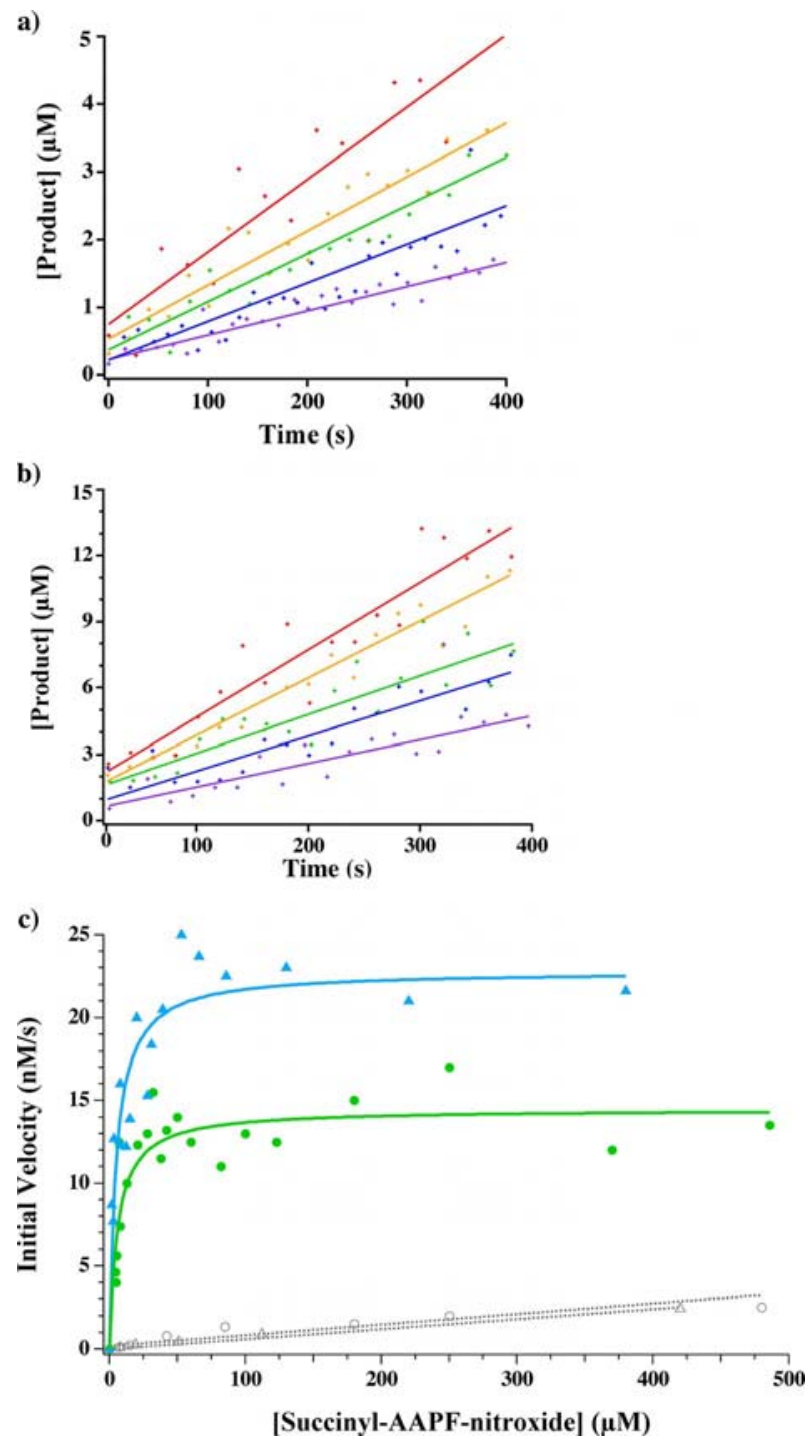

Figure 4. Selected curves of product generation kinetics from a range of substrates $3^{\circ}$ concentrations ( 5 to $250 \mu \mathrm{M}$ ) in the presence of chymotrypsin ( $2 \mathrm{~nm}$ ) in HEPES buffer $\mathrm{pH} 7.4$ at $25^{\circ} \mathrm{C}$. a) $(R)-3^{\circ}$ (red, orange, green, blue, violet symbols and lines for concentrations of $250,120,40,10$, and $5 \mu \mathrm{M}$ ); b) (S)- $3^{*}$ (red, orange, green, blue, violet symbols and lines for concentrations of $130,70,30,15$, and $10 \mu \mathrm{M})$. c) Initial velocities $\left(V_{0}\right)$ against substrate $3^{*}$ concentrations ( $\boldsymbol{\Lambda}$ for $(S)-3^{*}$, and $\bullet$ for $(R)-3^{*}$ ) in the presence of chymotrypsin (2 nM). Empty symbols for spontaneous hydrolysis. In (a) and (b), full lines are linear fit, and in (c) full lines (green for $(R)-3^{*}$ and blue for $\left.(S)-3^{*}\right)$ were fitted with Equation (1).

in vivo and ex vivo experiments. Hence, this method is a convenient approach for the detection of enzymatic activity in samples without any special preparation or denaturation of the samples.

Recently, ${ }^{[19]}$ we reported on the imaging of enzymatic activity by OMRI using a nonselective probe. Thus, as the high sensitivity to chymotrypsin activity of this substrate is very promising for future imaging of pancreatitis, a pancreatic disease resulting in a premature activation of the pancreatic digestive enzymes inside the pancreas. Imaging of this activation would allow an early diagnosis of the chronic form of the disease. In addition, the selectivity for cathepsin $\mathrm{G}$, a neutrophile protease 
which is a reliable inflammation marker, opens the door for a sensitive imaging method of inflammation.

Importantly, the procedure described for the preparation of $(S)-3^{\circ}$ and $(R)-3^{*}$ is robust enough to be applied to any type of peptides increasing the versatility of our probes provided the nitroxide is stable in the experimental medium. Thus, this approach can be extended to many types of enzymes in various fields of research.

\section{Acknowledgements}

All authors are grateful to ANR PULMOZYMAGE (ANR-15-CE180012-01) for the financial support. G.A., S.R.A.M., and I.G. are grateful to Aix-Marseille University, CNRS, and $A^{*}$ MIDEX for financial support (ANR-11-IDEX-0001-02). I.D. is grateful for the funding from the People Programme (Marie Curie Actions) of the European Union's Seventh Framework Program (FP7/20072013) under REA grant agreement no. PCOFUND-GA-2013609102, through the PRESTIGE program coordinated by Campus France.

[1] GBD 2015 Chronic Respiratory Disease Collaborators, Lancet Respir. Med. 2017, 5, $691-706$.

[2] K. Najima, J. C. Powers, B. Ashe, M. Zimmerman, J. Biol. Chem. 1979 $254,4027-14032$

[3] H. J. Halpern, in In Vivo EPR (ESR): Theory and Application (Ed.: L. J. Berliner), Springer, Boston, 2003, pp. $201-232$.

[4] K. Matsumoto, S. Subramanian, R. Murugesan, J. B. Mitchell, M. C. Krishna, Antioxid. Redox Signaling 2007, 9, 1125-1141.

[5] E. Terreno, D. D. Castelli, A. Viale, S. Aime, Chem. Rev. 2010, 12, 3019 3042.

[6] D. J. Lurie, I. Nicholson, J. R. Mallard, J. Magn. Reson. 1991, 95, 405-409.

[7] S. Matsumoto, H. Yasui, S. Batra, Y. Kinoshita, M. Bernardo, J. P. Munasinghe, H. Utsumi, R. Choudhuri, N. Devasahayam, S. Subramanian, J. B. Mitchell, M. C. Krishna, Proc. Natl. Acad. Sci. USA 2009, 106, 1789817903.

[8] J. Weaver, S. R. Burks, K. J. Liu, J. P. Kao, G. M. Rosen, J. Magn. Reson. 2016, 271, 68-74.

[9] B. Epel, S. V. Sundramoorthy, M. Krzykawska-Serda, M. C. Maggio, M Tseytlin, G. R. Eaton, S. S. Eaton, G. M. Rosen, H. J. Halpern, J. Magn. Reson. 2017, 276, $31-36$.
[10] T. Kawano, M. Murata, F. Hyodo, H. Eto, N. Kosem, R. Nakata, N. Hamano, J. S. Piao, S. Narahara, T. Akahoshi, M. Hashizume, Sci. Rep. 2016, 6, 32604.

[11] I. Dhimitruka, A. A. Bobko, T. D. Eubank, D. A. Komarov, V. V. Khramtsov, J. Am. Chem. Soc. 2013, 135, 5904-5910.

[12] J.-L. Clément, S. Barbati, C. Frejaville, A. Rockenbauer, P. Tordo, J. Chem. Soc. Perkin Trans. 2 2001, 1471-1475.

[13] W. Takahashi, A. A. Bobko, I. Dhimitruka, H. Hirata, J. L. Zweier, A. Samouilov, V. V. Khramtsov, Appl. Magn. Reson. 2014, 45, 817-826.

[14] S. Thétiot-Laurent, G. Gosset, J.-L. Clément, M. Cassien, A. Mercier, D. Siri, A. Gaudel-Siri, A. Rockenbauer, M. Culcasi, S. Pietri, ChemBioChem 2017, 18, 300-315.

[15] G. Audran, L. Bosco, P. Brémond, T. Butscher, S. R. A. Marque, Org. Biomol. Chem. 2016, 1288-1292.

[16] S. M. Hacker, C. Hintze, A. Marx, M. Drescher, Chem. Commun. 2014, $7262-7264$.

[17] E. Parzy, V. Bouchaud, P. Massot, P. Voisin, N. Koonjoo, D. Moncelet, J. M. Franconi, E. Thiaudiere, P. Mellet, PLoS One 2013, 8, e57946.

[18] N. Koonjoo, E. Parzy, P. Massot, M. Lepetit-Coiffe, S. R. A. Marque, J.-M. Franconi, E. Thiaudiere, P. Mellet, Contrast Media Mol. Imaging 2014, 9 $363-371$.

[19] G. Audran, L. Bosco, P. Bremond, J.-M. Franconi, N. Koonjoo, S. R. A. Marque, P. Massot, P. Mellet, E. Parzy, E. Thiaudiere, Angew. Chem. Int Ed. 2015, 54, 13379-13384; Angew. Chem. 2015, 127, 13577-13582.

[20] E. G. DelMar, C. Largman, J. W. Brodrick, M. C. Geokas, Anal. Biochem 1979, 99, 316-320.

[21] Other conditions such as $\mathrm{Mg}\left(\mathrm{ClO}_{4}\right)_{2}$ (see ref. [22]), $100^{\circ} \mathrm{C}$ (see ref. [23]), ammonium acetate (see ref. [24]) also failed to improve the yield of the reaction as well as the two-step procedure based on the generation of imine followed by addition of diethyl phosphite (see ref. [25]).

[22] S. Bhagat, A. K. Chakraborti, J. Org. Chem. 2007, 72, 1263-1270.

[23] E. Moreno-Pineda, F. Tuna, R. G. Pritchard, A. C. Regan, R. E. P. Winpenny, E. J. L. McInnes, Chem. Commun. 2013, 49, 3522-3524.

[24] Y.-J. Li, M.-Y. Ye, R.-Z. Huang, G.-Y. Yao, Y.-M. Pan, Z.-X. Liao, H.-S. Wang, Med. Chem. Res. 2014, 23, 3144-3156.

[25] E. D. Matveeva, T. A. Podrugina, E. V. Tishkovskaya, L. G. Tomilova, N. S. Zefirov, Synlett 2003, 2321-2324.

[26] J. Wu, W. Sun, W.-Z. Wang, H.-G. Xia, Chin. J. Chem. 2006, 24, $1054-$ 1057.

[27] P. Brémond, A. Koïta, S. R. A. Marque, V. Pesce, V. Roubaud, D. Siri, Org. Lett. 2012, 14, 358-361.

[28] C. Böhm, W. F. Austin, D. Trauner, Tetrahedron: Asymmetry 2003, 14, 71 74.

[29] CCDC: 1539640 and 1539639 for $\mathbf{5} \mathbf{a}$ and $\mathbf{5} \mathbf{b}$, respectively.

[30] M. Hollenstein, Chem. Eur. J. 2012, 18, 13320-13330.

[31] K. Yoshida, K. Yamaguchi, T. Sone, Y. Unno, A. Asai, H. Yokosawa, A. Matsuda, M. Arisawa, S. Shuto, Org. Lett. 2008, 10, 3571-3574.

[32] C. D. Chang, M. Waki, M. Ahmad, J. Meienhofer, E. O. Lundell, J. D. Haug, Int. J. Pept. Protein Res. 1980, 1, 59-66.

[33] For $2^{*}: a_{\mathrm{N}}=15.6 \mathrm{G}, a_{\mathrm{P}}=38.7 \mathrm{G}, g=2.0063$. See ref. [19].

[34] N. D. Rawlings, M. Waller, A. J. Barrett, A. Bateman, Nucleic Acids Res. 2014, 42, D503-509.

[35] I. Schechter, A. Berger, Biochem. Biophys. Res. Commun. 1967, 27, $157-$ 162. 